Choosing the Future for a Child with a Severe Hearing-Impairment

MARJATTA TAKALA, ELINA VILJAMAA, PÄIVI FREDÄNG

This is the peer reviewed version of the following article: Takala, M. , Viljamaa, E. and Fredäng, P. (2018), Choosing the Future for a Child with a Severe Hearing-Impairment. Support for Learning, 33: 204225. doi:10.1111/1467-9604.12201, which has been published in final form at https://doi.org/10.1111/1467-9604.12201.

This article may be used for non-commercial purposes in accordance with Wiley Terms and Conditions for Self-Archiving." 


\section{Choosing the Future for a Child with a Severe Hearing-Impairment}

\section{Introduction}

As most children who are deaf and severely hearing-impaired are born to hearing parents, their new situation can be confusing (Mitchell \& Kramer, 2004b). While each family reacts differently, strong emotions are commonplace, creating a need for support, as well as information (Moeller, Carr, Seaver, Stredler-Brown \& Holzinger, 2013; Nikula, 2015; Sume, 2008). Societal support is important, but these families also need peer support from other families in the same situation (Russ et al. 2004).

A significant body of research has addressed the literacy skills of children with a hearingimpairment (see Hermans et al. 2008; Lutz 2017, Mitchell \& Karchmer 2004a; Park et al. 2013; Qi \& Mitchell 2011). Many studies about school success of pupils with a hearing-impairment in general and, in particular, the superior reading skills of children with cochlear implants (Easterbrooks and Beal-Alvarez, 2012; Mayer, Watson, Archbold, Ng \& Mulla, 2016; Schorr et al. 2008). The consequences of using or not using Sign language (Hyde \& Punch, 2011; Spencer \& Marschark, 2010) have also been discussed. However, there is less research about the experiences of the family; in particular, there are few longitudinal observational studies of the choices families make, or of their daily life with a child having a severe hearing-impairment. The present study seeks to bridge this gap in the literature by exploring the experiences of families who have a child with a severe hearing impairment, based on a longitudinal questionnaire data. By illuminating families' choices and experiences in this way, we hope to give these parents a voice. Our results can offer new perspectives for families in this situation, as well as for experts, like teachers working with these families.

In Finland, hearing impairment is usually detected early, at the hospital where the child is born. The university hospital or the central hospital have the responsibility to share information to the families and to tell them about various rehabilitation services. The family can later on choose the day care 
setting and the school for their child. (Järvikoski, Martin, Autti-Rämö \& Härkäpää, 2013; Takala \& Sume, 2017)

\section{Field of Hearing and Field of Deafness}

As a theoretical frame, we draw on concepts from Bourdieu's distinction theory (1987a) and from his work on social and cultural capital (Bourdieu, 1986; see also Tzanakis 2013); the reflections and interpretations are our own. Bourdieu (1987a) asserted that cultural taste is defined by and has its origins in social networks and relations. Cultural choices tell us about an individual's cultural capital, and an individual's status is based on the amount and quality of their social, cultural and economic capital. There is an ongoing effort to maintain one's social status, with all the power and privileges that status entails (Bourdieu, 1998).

Bourdieu described society as comprising separate fields, arguing that there is a continuous struggle for power and governance of these fields. Social interactions occur in distinct fields, which vary in their logics. A field can be understood as an arena in which people fight for the resources they want (Bourdieu \& Wacquant, 1995). In this study, the relevant fields are characterized as the fields of hearing and of deafness.

The special capital acquired in a certain field is valuable in relation to that particular fieldfor example, Sign language in the field of deafness-but can be difficult to convert into a different form of capital. Newcomers to a given field need to know the rules and even the history of play (Bourdieu, 1987b). As hearing parents are completely unfamiliar with play and the rules in the deaf field, the hearing field can seem an easier choice. The cultural and social capital that hearing parents have acquired and respect is often based on oral language and on hearing. The suddenness of having a child who cannot hear may be experienced as a loss, both for the family and for the child: the lost possibility of singing together, of enjoying the sounds of nature, and certainly the loss of easy everyday communication. In these circumstances, it may be difficult to see the alternative possibilities to be gained by stepping into a new field (see also Nikula, 2015). 


\section{Communication and Additional Disability}

Decisions about what language to use must be made early in life with a child having severe hearingimpairment. The language variants recommended and used in these families range from oral-only to manual-only, with other options between. The debate about language variants can be seen as political - a power struggle concerning who has the right to decide what is preferable and therefore normal and desirable (Archbold \& Wheeler, 2010; Hyde \& Punch, 2011; Salmi \& Laakso, 2005; Söderfeldt, 2014). Both language possibilities and options for the education of deaf children changed significantly following the introduction of cochlear implants. With these implants, children can often learn to speak and hear well enough to be able to use oral language in many situations (Lonka, 2014), which also affects their education. In Finland, the first such implantation for a child was performed in 1997 (Kokkonen, Mäkiorkko, Roinen \& Ikonen, 2009).

In twenty-first century Finland, children with severe hearing-impairment are included in local schools. While a majority of these children now have implants, creating a Sign language environment within these institutions can be challenging (Punch \& Hyd,e 2010; Selin-Grönlund et al. 2014; Vermeulen, De Raeve, Langereis \& Snik, 2012). The positive learning outcomes (Marschark et al., 2012) and the possibility of using oral language with one's own son or daughter has encouraged many parents to opt for implantation, despite concerns about the risks of surgery (De Souza Vieira et al,. 2014). It seems that cochlear implantation makes it possible to share the family's heritage and social and cultural capital (see also Bourdieu, 1986, Bourdieu 1987a) in a way that differs from the use of Sign language and learning to live with deaf culture.

For all such decisions, one complicating factor is the prospect of an additional disability. While prevalence seems difficult to define (and statistics vary), about a third of children with a hearing impairment seem to have an additional disability such as visual impairment, specific language impairment or a syndrome of some kind. In such cases, Sign language or some form of 
signing is often preferred, in contrast to cases where a hearing impairment is the only disability (Edwards \& Crocker, 2008; Guardino \& Cannon, 2015; Punch \& Hyde, 2011; Spencer \& Marschark, 2010).

\section{Inclusive Education in Finland}

Children usually attend preschool in Finland, and there are no longer preschool groups exclusively for children with a hearing-impairment. When the hearing-impaired child reaches school age (in the year they turn seven), the family can choose either a regular school or a special setting. A child who needs individual support can now receive it in regular education, as every school has one or more special teachers to support these pupils (Halinen \& Järvinen, 2008; Takala \& Sume, 2017). Parents can apply for special support for their hearing-impaired child (Finnish National Board of Education, 2016), offering access to prolonged compulsory education, with smaller class sizes of no more than 20 pupils (Basic Education Act, 2010/893 2010). Smaller class sizes ensure better hearing conditions, as fewer pupils means less noise and more teacher time for each pupil. This is one reason to apply for special support, even though a child may not have a learning difficulty or developmental challenge (see Finnish Ministry of Education and Culture 2014). Although inclusive education now seems the preferred choice (Eriks-Brophy \& Whittingham, 2013), some parents choose segregated settings where they see their child's needs being met (Flaherty, 2015; Hender \& O’Neill, 2016). In 2010, $0.8 \%$ of pupils in regular education were hearing-impaired, presenting new challenges for preschool and school staff (Finnish Ministry of Education and Culture, 2014; Statistics Finland, 2010). While staff members initiate the inclusion process with pupils having hearing-impairment from the outset, parents often play the role of informants because of the family's greater experience of the child (see also Moeller et al., 2013).

\section{Method}


The study addresses two research questions: a) What do parents say about making decisions for their child with a severe hearing-impairment and do the decisions change during six years? and b) What do parents say about their experiences of everyday life with a child having a severe hearingimpairment?

We investigated the choices parents make about devices, communication and education. We also asked how they experience everyday life with their child who is deaf or severely hearing-impaired. Our data comprised longitudinal questionnaire data from 11 families, collected in 2008, 2009, 2011 and 2013. All of the participating families had one or two children who were deaf or severely hearing-impaired .

\section{Participants}

In the six-year follow-up study, parents of children who were deaf or had a severe hearingimpairment were asked to complete the same questionnaire (available from the first author) on four occasions (in 2008, 2009, 2011, and 2013). The participating families were originally contacted mainly through two associations: the Service Foundation for the Deaf and the Finnish Association of Parents of Deaf and Hard of Hearing Children. The parents received the questionnaire directly from these organizations, as the lack of a register of children having a hearing-impairment meant that the researchers had no access to the families' addresses. The aim was to reach families with a young child who was deaf or severely hearing-impaired not yet attending school. However, two families were accepted who had children already of school age at the beginning of the study period.

Only 11 families (with 13 deaf or severely hearing-impaired children) responded on three or four occasions. We focus here on those 11 families; results for the whole sample $(\mathrm{N}=29)$ have been presented and published elsewhere in Finnish (Takala \& Rainó, 2016). The children are listed according to age in Table 1. With one exception, all guardians were hearing, and all were white Finns. Four of the 11 children had a severe additional impairment such as a syndrome. Minor issues such as mild dyslexia were not classified as additional impairments. All but one of the children had 
at least one sibling. The ethical board was not contacted while the participants were parents who told about their own child. However, they were promised full anonymity. As Finland is so small, all used names are pseudonyms, and several details have been hidden or changed to prevent identification. (see also National Advisory Board on Research Ethics, 2009)

Table 1. Children and their backgrounds (all names are pseudonyms) [ABOUT HERE]

\section{Data Analysis}

Content analysis was used to examine the qualitative data (Hsieh \& Shannon, 2005; Mayring, 2000; Morse \& Field, 1995) and frequencies were used when useful. Following Hsieh and Shannon (2005, p. 1278), content analysis is defined here as 'a research method for subjective interpretation of the content of text data through systematic classification process of coding and identifying themes or patterns'. Written responses to questions were read several times by the researchers, and the material was then divided into subcategories. The main categories under which the key results are reported, were derived from these subcategories (see also Morse \& Field, 1995).

\section{Results}

Choice of device, communication and educational setting are discussed below, along with the changes observed in the data during the six-year follow-up.

\section{Decisions of choices}

None of the decisions about device, communication or education seemed easy or free of emotion, at least at some point (see also Roberson \& Shaw, 2015). In addition, some decisions revealed discrepancies. Older children with a hearing-impairment were involved in the decision-making, such as whether or not to have a second implant; otherwise, parents made the decisions. 


\section{Choice of Device and Communication}

Table 2 lists all hearing aids reported. Age at cochlear implantation is also set out in Table 1, revealing a trend towards implantations.

Table 2. Devices used by children [ABOUT HERE]

Mothers' and fathers' first and second communication methods in 2008 and in 2013 are shown in Table 3. The list shows the different expressions guardians used about the language variants.

Table 3. Guardians' 1st and 2nd communication method in 2008 and 2013 (11 children) [ABOUT HERE]

During the six-year study period, parents changed their way of communicating (Table 3). In the first year (2008), mothers used Sign language as the preferred option with two children and with three children during the last year (2013). Fathers used Sign language in 2008 with Axel, Frank, Harry and Mary, and in 2013 with Bea, Frank, Harry and Mary.

Unless the child had an additional impairment, siblings used speech and then signing as their primary communication system. Among the four with an additional impairment, three children's siblings used signing as their primary language, and one child's siblings used Sign language. Relatives and neighbours used speech, and some had some knowledge of signs. The first method of communication changed over the six years in two families. In Bea's family, signs changed to Sign language, making the language variant clearer. In Axel's case, his father first used Sign language in 2008, but in 2013, he used signed Finnish, which was closer to his own language. While other families did not change their primary communication method, the second language variant changed in six cases (see Table 4). In summary, speech was the primary method of communication with these 13 children; for eight of them, some form of signing was used as the second method. Sign 
language was used as the primary method of communication with children who had an additional impairment, or when the parent was deaf. In that family, the other parent used speech. In one family where the child had an additional impairment, the primary method was speech. While the deaf parent used only Sign language, other options were used with all the children; despite the relatively small sample size, communication methods varied. To summarize, it can be said that there were several ways of communicating when the parent was hearing and the child had severe hearing loss. Nobody reported just speaking.

Families hesitated about whether to use Sign language or just speak. The outcome was that they used both, or speech and cued speech with some signs, as two parents did. Cued speech is a system that makes all speech phonemes visible, using eight handshapes in four positions (for more information, see LaSasso et al., 2010). Content analysis of the open responses revealed two main categories in parent's texts concerning communication: Situated communication and Mainly speech.

\section{Situated Communication}

In this category, the situation determined which language or language variant was used. Methods other than oral communication became necessary when the child was not wearing a device-for example, in the early morning or late evening, in the sauna or when swimming, or when in noisy places.

'When he has the devices on, we just speak. When the other one is missing, speech is not enough; then we sign. If he has no device, we sign. We choose the communication according to the situation.' (Ken's mother, 2013)

In Finland, small children also have access to interpretation services (Kela 2016b), and some families described using these services as fine but not always functional. For example, it is important for a child to have the same interpreter so that they can get to know each other. As one parent explained, this could be difficult to organize. 
'She had an interpreter from the time she was 3 years old, in a congregation club. I ordered the interpreter to the meetings were very early and asked if it was possible to have the same interpreter. . . For a shy child, 20 club meetings and 17 different interpreters!' (Gaby's parent)

Signing seemed to give more degrees of freedom as Bea's mother tells.

'In the mornings, we start using Sign language and when dressing we help with the hearing-aids and then we start to speak.' (Bea's mother 2013)

\section{Mainly speech}

A child having cochlear implant or implants had usually learned to speak, so the family spoke.

However, if the parents or one parent was deaf, Sign language was used.

'Communication goes like with a speaking child. Only moments when there is not a cochlear implant in head are different, then we sign. We signed a lot and immediately after the operation development of speech has been really fast. When he started to hear our speech, we spoke and signed at the same time, and he understood everything.' (Ian's father, 2011)

Although speech was dominant, signing was a very practical help in many cases as Eva's mother tells. 'Sometimes he mishears and then we also sign.' (Eva's mother 2013).

\section{Choice of Education}

Responses related to institutional education revealed a desire for inclusion and normalization. This included speech and all the possibilities it offers. However, parents reported reluctance and even fear among preschool and school staff, claiming that some heads said they lacked the necessary resources to accommodate a child having a severe hearing-impairment with an additional impairment. Parents' choices regarding preschool and primary school are summarized in Table 4. 
Table 4. Educational choices made by parents [ABOUT HERE]

Although small, the group was diverse in terms of educational choices. In 2008, six children were in regular preschool, four were in special preschool, two were at a regular school and four attended a special school (Table 4). One child (Ken) spent half the day in special preschool and the other half in regular preschool. By the end of the study in 2013, one child was in regular preschool, four were at a special school, and eight were at a regular school.

During the first study year (2008), two children were at school; by 2013, all were at school. Three children (Ian, David and Eva) changed from a special educational setting to a regular setting, and three children with an additional impairment (Axel, Bea and Mary) changed from a regular to a special setting. School attendance often demands extra services - an individual educational plan, an FM device (frequency modulation), an assistant or a smaller class size — and parents reported having to be very involved in school issues to defend their child's rights. Parents in Szarkowski and Brice's (2016) study also referred to this advocacy role.

Again, choices were diverse: sometimes regular settings, sometimes special settings, with some switching between the two. Content analysis of the responses regarding education revealed two categories: Inclusive education and Impact of an additional disability.

\section{Inclusive education}

Many parents wanted their child into regular school. However, the various devices, like the FMdevice, were considered very important. Sometimes the child dropped from social situations while he/she did not hear.

'She uses an FM device during lessons. Communication goes well, and she likes to be at school. She is included when playing games (during the breaks) but does not hear so well.' (Jane's mother, 2011) 


\section{Impact of Additional Disability}

Two children with an additional disability attended a special school. Mary's family chose a special setting while they saw many benefits in it.

'She is now in special education, with individualized curriculum here in city $\mathrm{x}$, in the future perhaps in the state school for hearing-impaired. Language is Sign language.' (Mary's mother, additional impairment, 2009)

\section{Effects on Daily Life}

Content analysis revealed extremes in the effects of hearing impairment on the participating families' daily lives, ranging from almost no effect to affecting everything. Parents talked mainly about two things: Technical issues and A New World.

\section{Technical Issues}

In some responses, hearing impairment was described as a technical problem that could be overcome using appropriate devices. These need maintenance, and older children gained a positive sense of independence from being able to take care of their hearing aid. In another case, the child's hearing loss was an issue when designing and building the family home, making it more than a minor technical issue. This example lies in the middle of the continuum from no changes to several changes.

\section{A New World}

Parents whose first child is not hearing-impaired can compare life with a child having a hearingimpairment. Bea's father said they had experienced big life changes, comparing these to a religious awakening because so many things changed. He also noted that the family could tire of all the therapies, Sign language lessons and meetings with various experts. For example, having a child 
who uses Sign language changes many leisure activities. Nevertheless, they also experienced it as normal, regular life with small children.

\section{Discussion}

A questionnaire was sent four times in a six-year period to eleven families with a child having severe hearing-impairment. The study focused on the choices families made and how they experienced daily life with their child. Decision processes in relation to communication methods were described in terms of hesitation, uncertainty and frustration with conflicting information, and ultimately relief following functional, good or perhaps even right decisions (see also Nelson, Caress \& Grenny, 2012).

A cochlear implant (or two implants) was chosen if considered beneficial. Unlike an American study with parents of hearing-impaired children (Szarkowski \& Brice, 2016), no financial concerns were mentioned here. This is probably because the government pays for most medical and technical care in Finland. Choosing implantation can be interpreted as choosing hearing culture, implying a desire to transfer one's own cultural and social capital—often based on oral language and sound-based cultural forms such as music — to one's own son or daughter.

These decisions changed somewhat during the six-year study period. For example, a hearing aid was changed to a cochlear implant, or one implant was not considered good enough, and the child received a second one. While regular education was a common choice, some parents opted for special education or were advised to do so. Often but not always, a child with an additional impairment attended a special setting. Even when a regular setting was chosen, special support was applied for in order to access all the necessary support services.

Regardless of the child's age, all families used more than one communication system. They spoke but also decided to use other methods - mainly signs as support or signed Finnish. The use of Sign language and signing diminished over the study period, and speech became more dominant. 
Several families reported being told by the hospital not to use Sign language at all, but they had not complied (see also Decker et al., 2012; Hyde \& Punch, 2011; Watson et al., 2008). Along with changes in the child's situation, society also changed. Technology continued to develop, and the school system became more inclusive (see for example Eriks-Brophy \& Whittingham, 2013; Hausstätter, 2014; Rytivaara, 2012). Although a hearing impairment is invisible and may go unnoticed, its effects on everyday life range from small technical issues to transformation in several fields, involving new friends, language and culture.

The story revealed from the longitudinal data is not homogeneous or indicative of clear choices. It is a story of hesitation, diversity and tailor-made solutions, entailing variety and flexibility. One key finding is that hearing parents want their child to have access to hearing culture and the hearing world. If we consider the hearing and deaf world as fields (Bourdieu \& Wacquant, 1995), we can say that parents want their children to inhabit a familiar field. They may also occasionally visit the field of deafness; for instance, one family with deaf and hearing guardians moved flexibly from field to field. However, these concepts borrowed from Bourdieu (1986) show that the situation is not binary, as a third field — diverse communication—also seems useful. Families visit this field in situations where oral language cannot be used and their own skills in Sign language are modest. This is an in-between field, where hearing and deaf fields overlap.

Given the limited number of participants, all of whom were active members of associations for the hearing-impaired, there is a risk of bias. However, our findings align with other research (Lyngbäck, 2016; Selin-Grönlund et al., 2014; Spencer \& Marschark, 201; Takala \& Rainó, 2016; Watson et al., 2008), which strengthens their credibility and transferability (see Lincoln \& Guba, 1985).

As in our study, Watson, Hardie, Archbold \& Wheeler (2008) found that guardians of children who were deaf or severely hearing-impaired were pragmatic; they saw the benefits of using two languages or language variants, and they were not dogmatic about communication methods. 
As these children grow up, they will think increasingly about issues of identity. They will make their own choices, perhaps based on multiple factors other than hearing or communication, leading perhaps to a fluid identity (see Kemmery \& Compton, 2014) that changes according to the context (Rich, Levinger, Werner \& Adelman, 2013; Schorr, 2006). These children may want to integrate in hearing culture as well as in deaf culture. Hollins (2000) discussed the possible marginalization or social exclusion of individuals with cochlear implants as neither wholly in the deaf or the hearing community. Nevertheless, the future of the children in this study seems bright. They have opportunities to become multicultural in a new way, moving between different cultural fields as they prefer. They have more than one means of communicating. In the diversity of languages and all that it gives them, they have huge capital. The next step in this research is to interview the children to ask them about their choices.

\section{Disclosure statement}

The authors report no conflicts of interest.

\section{References}

Albertini, J.A. \& Hintermair, M. (2005). Ethics, deafness, and new medical technologies. Journal of deaf studies and deaf education, 10(2), 184-192. doi:10.1093/deafed/eni018

Archbold, S. \& Wheeler, A. (2010). Cochlear implants: family and young people's perspectives. In: M. Marschark and P. Spencer, eds. Oxford handbook of deaf studies, language and education (vol. 2). (pp. 226-240). New York: Oxford University Press.

Basic Education Act. (2010). 2010/893. Forming teaching groups, § 2, clause 3. Available from: http://www.finlex.fi/fi/laki/ajantasa/1998/19980852 
Bourdieu, P. (1986). The forms of capital. In: J. Richardson, ed. Handbook of theory and research for the sociology of education. (pp. 241-258). New York: Greenwood.

Bourdieu, P. (1987a). Distinction. A social critique of the judgement of taste (R. Nice, trans.). Harvard University Press. (Original work published 1979)

Bourdieu, P. (1987b). Sosiologian kysymyksiä [Questions of sociology] (J.-P. Roos, trans.). Jyväskylä, Finland: Vastapaino.

Bourdieu, P. \& Wacquant, L.J.D. (1995). Refleksiiviseen sosiologiaan: Tutkimus, käytäntö ja yhteiskunta [Invitation to reflexive sociology]. Joensuu, Finland: Joensuu University Press.

Decker, K.B., Vallotton, C.D., \& Johnson, H.A. (2012). Parents' communication decision for children with hearing loss: sources of information and influence. American annals of the deaf, 157(4), 326-339. Available from: https://www.learntechlib.org/p/113529/

De Souza Vieira, S., Bevilacqua, M. C., Ferreira, N. M. \& Dupas, G. (2014). Cochlear implant: the complexity involved in the decision-making process by the family. Revista Latino Americana de Enfermagem, 22(3), 415-424. doi:10.1590/0104-1169.3044.2432.

Easterbrooks, S.R. \& Beal-Alvarez, J-S. (2012). States' reading outcomes of students who are d/Deaf and hard-of-hearing. American annals of the deaf, 157(1), 27-40. Available from: http://web.b.ebscohost.com.pc124152.oulu.fi:8080/ehost/pdfviewer/pdfviewer?vid=1\&sid=e2 35a704-5664-4d28-92bd-f404b23e331d\%40sessionmgr101

Edwards, L. \& Crocker, S. (2008). Psychological processes in deaf children with complex needs: an evidence-based practical guide. London: Kingsley.

Eriks-Brophy, A. \& Whittingham, J. (2013). Teachers' perceptions of the inclusion of children with hearing loss in general education settings. American annals of the deaf, 158(1), 63-97. doi:10.1353/aad.2013.0009 
Finnish Association of Parents of Deaf and Hard of Hearing Children. (2017). Information. Available from: http://www.klvl.org/muut-kielet/finnish-association-of-parents-of-the-deafand-hard-of-hearing-children-the-klvl/

Finnish Ministry of Education and Culture. (2014). Oppimisen ja hyvinvoinnin tuki. Selvitys kolmiportaisen tuen toimeenpanosta [Support for learning and well-being. Clarification of the implementation of three step support]. Publications of Ministry of Education and Culture 2014:2. Available from:

http://www.minedu.fi/export/sites/default/OPM/Julkaisut/2014/liitteet/okm02.pdf?lang=fi

Finnish National Board of Education. (2016). Miten erityisen tuen päätös tehdään? [How to make a decision for special support?]. Available from:

http://www.oph.fi/saadokset_ja_ohjeet/ohjeita_koulutuksen_jarjestamiseen/perusopetuksen jarjestaminen/tietoa_tuen_jarjestamisesta/erityinen_tuki/erityisen_tuen_paatoksen_tekemine $\underline{\text { n } 2016}$

Flaherty, M. (2015). What we can learn from hearing parents of deaf children. Australasian journal of special education, 39(1), 67-84. https://doi.org/10.1017/jse.2014.19

Guardino, C. \& Cannon, J.E. (2015). Theory, research, and practice for students who are deaf and hard of hearing with disabilities: addressing the challenges from birth to postsecondary education. American Annals of the Deaf, 160(4), 347-355. doi:10.1353/aad.2015.0033

Halinen, I. \& Järvinen, R. (2008). Towards inclusive education. The case of Finland. Prospects, 38(1), 77-97. doi:10.1007/s11125-008-9061-2

Hausstätter, R.S. (2014). In support of unfinished inclusion. Scandinavian journal of educational research, 57(4), 424-434. http://dx.doi.org/10.1080/00313831.2013.773553 
Hender, O. \& O’Neill, R. (2016). Monitoring the achievement of deaf pupils in Sweden and Scotland: approaches and outcomes. Deafness \& education international, 18(1), 47-56. http://dx.doi.org/10.1080/14643154.2016.1142045

Hermans, D., Knoors, H., Ormel, E. \& Verhoeven, L. (2008). The relationship between the reading and signing skills of deaf children in bilingual education programs. Journal of deaf studies and deaf education, 13(4), 518-30. doi:10.1093/deafed/ent024

Hollins, K. (2000). Between two worlds: the social implications of cochlear implantation for children born deaf. In: J. Hubert, ed. Madness, disability and social exclusion: The archaeology and anthropology of 'difference'. (pp. 180-195). London: Routledge.

Hsieh, H.-F. \& Shannon, S.E. (2005). Three approaches to qualitative content analysis. Qualitative health research, 15(9), 1277-1288. doi:10.1177/1049732305276687

Hyde, M. \& Punch, R. (2011). The modes of communication used by children with cochlear implants and the role of sign in their lives. American Annals of the Deaf, 155(5), 535-549. doi: 10.1353/aad.2011.0006

Järvikoski, A.; Martin, M.; Autti-Rämö, I.; Härkäpää, K. (2013). Shared agency and collaboration between the family and professionals in medical rehabilitation of children with severe disabilities. International Journal of Rehabilitation Research, 36(1), 30-37.

Kela [The Social Insurance Institution of Finland]. (2016a). Rehabilitation services. Available from: http://www.kela.fi/web/en/rehabilitation

Kela [The Social Insurance Institution of Finland] (2016b). Interpreter services for disabled. Available from: http://www.kela.fi/vammaisten-tulkkauspalvelut

Kemmery, M.A. \& Compton, M.V. (2014). Are you deaf or hard of hearing? Which do you go by: perceptions of identity in families of students with hearing loss. Volta review, 114(2), 157192. Available from: https://search.proquest.com/docview/1553208993 
Kokkonen, J., Mäkitorkko E., Roine, R. \& Ikonen, T. (2009). Vaikea-asteisen kuulovian kuntoutus molemminpuolisen sisäkorvaistutteen avulla [Rehabilitiation of a severe hearing impairment with a cochlear implant]. Suomen Lääkärilehti, [Finnish medical journal], 64(17), 15671577.

LaSasso, C., Crain, K.L., \& Leybaert, J. (2010). Cued speech and cued language development for deaf and hard of hearing children. San Diego, CA: Plural.

Lincoln, Y.S. and Guba, E.G. (1985). Naturalistic inquiry. Beverly Hills, CA: Sage.

Lonka, E. (2014). From silence to sounds. Outcomes of cochlear implantation in Finnish adults and children. Unpublished thesis. University of Helsinki.

Lutz, L. (2017). The Early Years: Parents and Young Deaf Children Reading Together. Odyssey: New Directions in Deaf Education, 18, 4-10.

http://www3.gallaudet.edu/Documents/Clerc/Odyssey/2017_issue/ODYSSEY_2017-

3_Lutz.pdf

Lyngbäck, L.A. (2016). Experiences, networks and uncertainty: parenting a child who uses a cochlear implant. Thesis. Institute of Pedagogy and Didactics, Stockholm University.

Marschark, M., Lang, H.G., \& Albertini, J.A. (2012). Educating deaf students. From research to practice. Oxford: Oxford University Press.

Martikainen, L. \& Rainò, P. (2014). Sisäkorvaistutetta käyttävien lasten ja nuorten kuntoutus- ja tulkkauspalvelujen toteutuminen ja tarve tulevaisuudessa [The situation and future need for rehabilitation and interpretation services for young children and youth using a cochlear implant]. Research reports of Social and Healthcare 89/2014. Helsinki, Finland: Kela (The Social Insurance Institute of Finland) Research Department. Available from: https://helda.helsinki.fi/bitstream/handle/10138/144490/Selosteita89.pdf?sequence=28

Mayer, C.; Watson, L.; Archbold, S.; Ng, Z. Y. \& Mulla, I. (2016). Reading and Writing Skills of Deaf Pupils with Cochlear Implants. Deafness \& Education International, 18(2), 71-86. 
Mayring, P (2000). Qualitative content analysis. Forum: qualitative social research, 1(2), article 20. Available from: http://www.qualitative-research.net/index.php/fqs/article/view/1089/2385

Mitchell, R.E. \& Karchmer, M.A. (2004a). When parents are deaf versus hard of hearing: patterns of sign use and school placement of deaf and hard-of-hearing children. Journal of deaf studies and deaf education, 9(2), 133-152. doi: 10.1093/deafed/enh017

Mitchell, R. \& Karchmer, M. (2004b). Chasing the mythical ten percent. Parental hearing status of deaf and hard of hearing students in the United States. Sign language studies, 4(2), 138-163.

Moeller, M.P., Carr, G, Seaver, L., Stredler-Brown, A. \& Holzinger, D. (2013). Best practices in family-centered early intervention for children who are deaf or hard of hearing: an international consensus statement. Journal of deaf studies \& deaf education, 18(4), 429445. doi:10.1093/deafed/ent034

Morse, J.M. \& Field, P.A. (1995). Qualitative research methods for health professionals. 2nd ed. Thousand Oaks, CA: Sage.

National Advisory Board on Research Ethics. 2009. Ethical principles of research in the humanities and social and behavioural sciences and proposals for ethical review. Available from: http://www.tenk.fi/sites/tenk.fi/files/ethicalprinciples.pdf

National Association of Cochlear Implanted Children. (2017). Information. Available from: http://www.lapci.fi/in-english/

Nelson, P.A., Caress, A.L. \& Grenny, A.M. (2012). 'Doing the "right” thing': How parents experience and manage decision-making for children's 'normalising' surgeries. Social science \& medicine, 74(5), 796-804. doi:10.1016/j.socscimed.2011.11.024

Nikula, K. (2015). Lapsen hyvää edistämässä. Sisäkorvaistutehoitokäytännön sosiaalieettistä tarkastelua [Promoting the well-being of a child. Socioethical inspection of cochlear implant practices] Thesis (PhD). University of Helsinki.

Park, J., Lombardino, L.J., \& Ritter, M.J. (2013). Phonology matters: a comprehensive investigation 
of reading and spelling skills of school-age children with mild to moderate sensorineural hearing loss. American Annals of the Deaf, 158(1), 20-40.

http://web.a.ebscohost.com.pc124152.oulu.fi:8080/ehost/pdfviewer/pdfviewer?vid=1\&sid=f2 d0b14b-e1ae-43c3-95bd-18ae13ad9994\%40sessionmgr4007

Punch, R. \& Hyde, M. (2010). Children with cochlear implants in Australia: educational settings, supports and outcomes. Journal of deaf studies and deaf education, 15(4), 405-421. doi:10.1093/deafed/enq019

Punch, R. \& Hyde, M. (2011). Communication, psychosocial, and educational outcomes of children with cochlear implants and challenges remaining for professionals and parents. International journal of otolaryngology, 1-10. doi: 10.1155/2011/573280

Qi, S. \& Mitchell, R. (2011). Large-scale academic achievement testing of deaf and hard-of-hearing students: past, present and future. Journal of deaf studies and deaf education, 17(1), 1-17. doi: 10.1093/deafed/enr028

Rich, S., Levinger, M., Werner, S. \& Adelman, C. (2013). Being an adolescent with a cochlear implant in the world of hearing people: coping in school, in society and with self-identity. International journal of pediatric otorhinolaryngology, 77(8), 1337-1344. doi:

10.1016/j.ijporl.2013.05.029

Roberson, L. \& Shaw, S. (2015). Reflections on deaf education: perspectives of deaf senior citizens. Educational gerontology, 41(3), 226-237. http://dx.doi.org/10.1080/03601277.2014.951194

Russ, S.A., Kuo, A. A., Poulakis, Z., Barker, M., Rickards, F., Saunders, K., Jarman, F. C., Wake, M. \& Oberkleid, F. (2004). Qualitative analysis of parents' experience with early detection of hearing loss. Archives of disease in childhood, 89(4), 353-358.

doi:10.1136/adc.2002.024125 
Rytivaara, A. (2012). Towards inclusion-teacher learning in co-teaching. Thesis. University of Jyväskylä. Jyväskylä studies on education, psychology and social research, 453.

Salmi, E. \& Laakso, M. (2005). Maahan lämpimään—Suomen viittomakielisten historia [To a warm country-The history of Finnish Sign language users]. Helsinki: Finnish Deaf Association.

Schorr, E. (2006). Early cochlear implant experience and emotional functioning during childhood: Loneliness in middle and late childhood. The Volta review, 106, 365-379. Available from: https://www.agbell.org/uploadedFiles/Connect/Publications/The_Volta_Review/TVR_1063.pdf

Schorr, E., Roth, F., \& Fox, N. (2008). A comparison of the speech and language skills of children with cochlear implants and children with normal hearing. Communication disorders quarterly, 29(4), 195-201. doi: 10.1177/1525740108321217

Selin-Grönlund, P., Rainò, P., \& Martikainen, L. (2014). Kuurojen ja viittomakielisten oppilaiden lukumäärä ja opetusjärjestelyt. Selvitys lukuvuoden 2013-2014 tilanteesta [The amount and teaching arrangements of deaf and Sign language users]. Reports and clarifications, 11. National Board on Education, the Finnish Deaf Association. Available from: http://www.oph.fi/download/158006_kuurojen_ja_viittomakielisten_oppilaiden_lukumaara ja_opetusjarjestelyt.pdf

Service Foundation for the Deaf. (2017). Information. Available from: https://www.kuurojenpalvelusaatio.fi/en/

Söderfeldt, Y. (2014). An evening of equality? Nationalism and the centennial celebration of the Berlin Royal Deaf-Mute Asylum, December 2-4, 1888. Sign language studies, 14(2), 250265.

Spencer, P.E. \& Marschark, M. (2010). Evidence-based practice in education deaf and hard-ofhearing students. Oxford: Oxford University Press. 
Statistics Finland. (2010). Comprehensive school pupils transferred to special education by ground for decision of acceptance or transfer in 2010. Available from http://www.stat.fi/til/erop/2010/erop_2010_2011-06-09_tau_004_en.htm

Sume, H. (2008). Perheen pyörteinen arki. Sisäkorvaistutetta käyttävän lapsen matka kouluun [Turbulent life of the family....way to school of a child with cochlear implant]. Unpublished thesis. University of Jyväskylä, Finland. Available from: https://jyx.jyu.fi/dspace/bitstream/handle/123456789/18548/9789513932008.pdf?sequence= 1

Szarkowski, A. \& Brice, P.J. (2016). Hearing parents' appraisals of parenting a deaf or hard-ofhearing child: application of a positive psychology framework. Journal of deaf studies and deaf education, 21(3), 249-258. doi:10.1093/deafed/enw007

Takala, M. \& Raino, P. 2016. Kieli, kojeet ja koulutus? Kuulovammaisten lasten perheet valintojen edessä. [The families of hearing-impaired children facing choices]. Niilo Mäki Bulletin, 2, 27-42. Abstract available from: https://bulletin.nmi.fi/article/kieli-kojeet-ja-koulutuskuulovammaisten-lasten-perheet-valintojen-edessa/

Takala, M. \& Sume, H. (2017). Hearing-Impaired Pupils in Mainstream Education in Finland Teachers' Experiences of Inclusion and Support. European Journal of Special Needs Education, 33(1), 134-147. dx.doi.org/10.1080/08856257.2017.1306965.

Tzanakis, M. (2013). Social capital in Bourdieu's, Coleman's and Putnam's theory: empirical evidence and emergent measurement issues. Educate, 13(2), 2-23. Available from: http://www.educatejournal.org/index.php/educate/article/view/366/293

Vermeulen, A., De Raeve, L., Langereis, M. and Snik, A. (2012). Changing realities in the classroom for hearing-impaired children with cochlear implant. Deafness and education international, 14(1), 36-47.

http://dx.doi.org.pc124152.oulu.fi:8080/10.1179/1557069X12Y.0000000004 
Watson, L.M., Hardie, T., Archboald, S.M. \& Wheeler, A. (2008). Parents' views on changing communication after cochlear implantation. Journal of deaf studies and deaf education, 13(1), 104-116. https://doi.org/10.1093/deafed/enm036 